\title{
ENERGY, EXERGY AND THERMOECONOMIC ANALYSIS OF A NATURAL GAS ASSISTED GEOTHERMAL CENTRAL HEATING SYSTEM
}

\author{
Nurettin YAMANKARADENIZ \\ Orhan SAHMERDAN
}

Received: 17.12.2020; revised: 24.09.2021; accepted: 24.09.2021

\begin{abstract}
In this work, a natural gas assisted geothermal central heating system in northwestern Turkey utilising low enthalpy geothermal fluid and natural gas as the sources for space heating was analyzed.The study comprised energy, exergy and thermoeconomic analyses of the system under hybrid operating conditions (i.e., from 1 January 2020 to 31 March 2020). The data were collected from a basis of the facility which operates the system. The values about the heat pumps were obtained from the department of the sales company in Istanbul, Turkey and the 'Average Values for Hybrid Case' were determined. This work covers energetically, exergetically and thermoeconomically assessment of the system in question through its all stages. The results were found with regard to the system performance investigation. The whole system efficiencies of energy and exergy were found as $56.77 \%$ and $49.93 \%$ respectively. The exergy cost value per hour and the thermoeconomic factor were calculated as $411.242 € / \mathrm{h}$ and $9.8 \%$ respectively.
\end{abstract}

Keywords: Energy, Exergy, Thermoeconomic Analysis

Bir Doğalgaz Destekli Jeotermal Merkezi Isıtma Sisteminin Enerji, Ekserji ve Termoekonomik Analizi

Öz: Bu çalışmada, alan ısıtması için kaynak olarak düşük entalpili jeotermal akışkan ve doğalgaz kullanan ve Türkiye'nin kuzeybatısında bulunan doğalgaz destekli bir jeotermal merkezi 1sıtma sisteminin analizi yapılmıştır. Çalışma, sistemin hibrit çalışma şartları altında ( 1 Ocak 2020'den 31 Mart 2020'ye kadar ) enerji, ekserji ve termoekonomik analizden oluşmaktadir. Veriler sistemi kullanan işletmeden toplanmıştır. Isı pompalarına ait kapasite değerleri ise satıcı firmanın İstanbul, Türkiye'deki şubesinden elde edilmiştir ve 'Hibrit Durum İçin Ortalama Değerler' tespit edilmiştir. Bu çalışma, söz konusu sistemin tüm aşamalarındaki enerjetik, ekserjetik ve termoekonomik değerlendirmesini kapsamaktadır. Sonuçlar, sistem performansının incelenmesine dayalı olarak bulunmuştur. Tüm sistemin enerji ve ekserji verimi sırasıyla $\% 56,77$ ve $\% 49,93$ olarak bulunmuştur. Saatlik ekserji maliyeti ve termoekonomik faktör sırasıyla $411,242 € / \mathrm{h}$ ve $\% 9,8$ olarak hesaplanmıştır.

Anahtar Kelimeler: Enerji, Ekserji, TermoekonomikAnaliz

\footnotetext{
* Uludağ University, Faculty of Engineering, Department of Mechanical Engineering, 16059 Bursa, Turkey, Correspondence Author: Nurettin YAMANKARADENIZ (nyk@uludag.edu.tr)

** Uludağ University, Institude of Science, Department of Mechanical Engineering, 16059 Bursa, Turkey
} 
Yamankaradeniz N., Sahmerdan O.: Energy Exergy Analysis. of a Geothermal Htg. Sys.

\section{INTRODUCTION}

While anyone has an understanding about energy, it is a bit difficult to define it exactly.Energy can be described as a factor what causes change (Boles and Cengel, 1989). It is the most essential need for the continuation of human life, from waking up in the morning to going to bed in the night. The need for energy is rising day after day. All segments in life are deeply bound up with energy, from communication and transportation to industry and the comforts of the home and business offices and even homeland security ( Singh and Dwevendi, 2019 ).

The global demand for energy has been increasing since the industrial revolution with regard to prosperity (Bhowmika et.al. 2017). Meeting this increasing demand is one basic hardships at this time (Acar and Dincer, 2017). Currently, about $80 \%$ of energy demand in the world is covered by fossil fuels (Aleixandre-Tudo et.al. 2019). Producing and consuming energy by fossil fuels along with biomass and some other sorts of renewable energy is leading to emissions of greenhouse gases $(\mathrm{GHG})$ such as nitrous oxides $\left(\mathrm{NO}_{\mathrm{x}}\right)$, sulphur oxides $\left(\mathrm{SO}_{\mathrm{x}}\right)$, dust and particulate matters $\left(\mathrm{PM}_{\mathrm{S}}\right)$ which pollute the environment. (Wang et.al. 2019). The negative effects of greenhouse gases stem from energy usage and leave a negative impact on culture and life standards. Environmental problems also impact the regularity of countries' economies so then are significant conserns. It appears to be that there is a close relationship between energy consumption and $\mathrm{CO}_{2}$ emission (Acar and Dincer, 2017 ).

Using renewable energy can decrease dependency on fossils, detrimental pollutants from energygeneration and consumption, and GHG emissions. Geothermal energy is a renewable energy sort coming from the heat of the magma what is the core of the earth (Noorollahi et.al. 2019). It is described as a clean, environmentally friendly and cheap renewable energy sort (Herez et.al. 2017). Also geothermal energy systems can supply cost efficient resources for facilities. This energy sort is more long-lasting, consistent and reliable in comparison with other renewable energy sources such as wind energy and solar energy (Soltani et.al., 2019). Natural gas is the cleanest fossil fuel compared to other fossil fuels. Because three major components those pollute the environment $\left(\mathrm{SO}_{2}, \mathrm{PM}\right.$ and smut) do not exist in natural gas smoke (Imal et.al., 2013).

In previous studies, the usage of natural gas with geothermal energy is mostly based on the recovery of LNG cold energy for regasification process rather than the direct use of natural gas in contrast with the current system. For instance, Ebadollahi et al. (2019) proposed a geothermal based system utilising LNG cold energy to produce heating, electricity power, cooling outputs and hydrogen production and is constituted of four subcycles: an ORC (Organic Rankine Cycle), an ERC (ejector refrigeration cycle) and PEM ( proton exchange membrane) cycle. In this system, a refrigerant fluid that circulates in ORC and ERC draws geothermal and LNG cold energy to generate electricity, heating and cooling power. Also, geothermal fluid that gives some of it heat to the ORC enters the PEM unit along with power extracted from LNG turbine to produce $\mathrm{H}_{2}$. The energy and exergy efficiencies and the exergy destruction cost of the system were calculated $38.33 \%$, $28.91 \%$ and 43004 \$year. Ghaebi et al. (2018) carried out an energy, exergy and thermoeconomic evaluation about an absorption refrigeration based system driven by geothermal and LNG cold energy to provide power, heating and cooling commodities. They deduced thathigher energy and exergy efficiencies can be acquired by low condenser and absorber temperatures along with higher evaporator temperature. Employing the heating unit at high temperature decreases both the total cost of product and thermal efficiency of the system. Boyaghchi et al. (2015) conducted an optimization work on a novel system employing geothermal and solar energiesto output heating, cooling and power capacities. In their system, solar and geothermal energies contributes to an ORC via the water/CuO nanofluid and brine to produce commodities. They measured the affects of 
using different working fluids in the ORC to the system performance and the total area of heat exchangers. They discovered that the best option from the thermodynamic perspective is R134a with $52.08 \%$ and $3.19 \%$ of thermal and exergetic efficiencies respectively. Exergoeconomically, R1234 is the best selection with 5267.91 \$/year of total product cost while R423A is the best fluid with $116.984 \mathrm{~m}^{2}$ of total minimum exchangers area.Ezzat and Dincer (2016) analyzed a novel geothermal-solar based multigeneration system producing cooling power for industry, hot water and heating power for domestic applications, electricity power and food dry capacity. This system is made of those subsystems: a single flash geothermal cycle connected to the heat pump cycle, anabsorption cooling cycle, drying and hot water systems, a thermal storage linked with the ancillary steam turbine. They assessed this system from thermodynamic viewpoints and found energy and exergy efficiencies of the system $69.6 \%$ and $42.8 \%$ respectively. They also examined changing a variety of system variables and observed its effects on thermodynamic efficiencies of subsystems and the overall system. They extracted that the energy efficiency of the overall system occurs approximately five times higher than the basic geothermal system. Rostamzadeh et al. (2019) presented an optimization study on a multigeneration system using a geothermal-biogas heat source and constituded of some subsystems such as BSR (biogas steam reforming), KC (Kalina cycle), LNG subsystem to output heating, cooling, freshwater and hydrogen. They examined the system from the thermodynamic, thermoeconomic and environmental standpoints presenting a parametric study based on the basic operating conditions and experiencing different working modes. They extracted that the system studied is economically a profitable tool for districts taking advantage from biogas and low enthalpy geothermal source. Blazquez et.al. (2018) compared three geothermal heating systems; adistrict heating geothermal system providing heat by only geothermal energy, a district heating geothermal plant supported by an individual natural gas system and finally a geothermal plant operated with a natural gas boiler. They concluded that the first geothermal system is the best option from both economic and environmental perspectives.

Even if there is a natural gas-assisted geothermal heating system driving low enthalpy geothermal fluid in Inegol, Bursa / Turkey, there has not been a comprehensive thermodynamic and thermoeconomic study on it. Also, reviewing the literature, it can be seen that the use of natural gas to support geothermal systems is mostly based on LNG cold energy recovery and there is a lack of assessment about geothermal systems driven by natural gas used directly (by combustion). The main goals of this work are to bridge this gap and compare the current system with a fore-mentioned type of systems.

\section{MATERIALS AND METHOD}

\subsection{System description and working principle}

A schematic representation of the Oylat geothermal heating system (GHS) is given in Figure 1. It is a natural gas assisted GHS located $79 \mathrm{~km}$ southeast of the city of Bursa in northwestern Turkey. The geothermal fluid springs from the production spontaneously. The facility started service in 2016. The Oylat GHS has a heat capacity of $1350 \mathrm{kWh}$ and consists of four heat transfer cycles (HTC).

The Oylat GHS utilizes a low-temperature geothermal water at $40{ }^{\circ} \mathrm{C}$ and natural gas as the source of energy input for heat production. The system has liquid-dominated geothermal water characteristic at low temperature. Geothermal water heat is conducted to the HP-HE cycle via the stainless steel heat exchangers (SSHE) settled in the geothermal pool in where the geothermal water enters at $40{ }^{\circ} \mathrm{C}$ and at a rate of $50 \mathrm{~kg} / \mathrm{s}$ and exists at $35^{\circ} \mathrm{C}$. Circulating water 
in the HP-HE cycle enters the heat exchangers (HE) at $20^{\circ} \mathrm{C}$ and leaves those HEs at $30{ }^{\circ} \mathrm{C}$. Heat acquired by the HEs is transferred to water circulates in the HP-AT cycle via the two heat pumps (HP).The circulating water in the HP-AT cycle enters the second and first HPs at respectively $50{ }^{\circ} \mathrm{C}$ and $55^{\circ} \mathrm{C}$ and leaves the first $\mathrm{HP}$ at $60^{\circ} \mathrm{C}$. Afterwards, the HP-AT cycle conducts the heat obtained via HPs to the storaged water in the accumulating tank (AT) group.

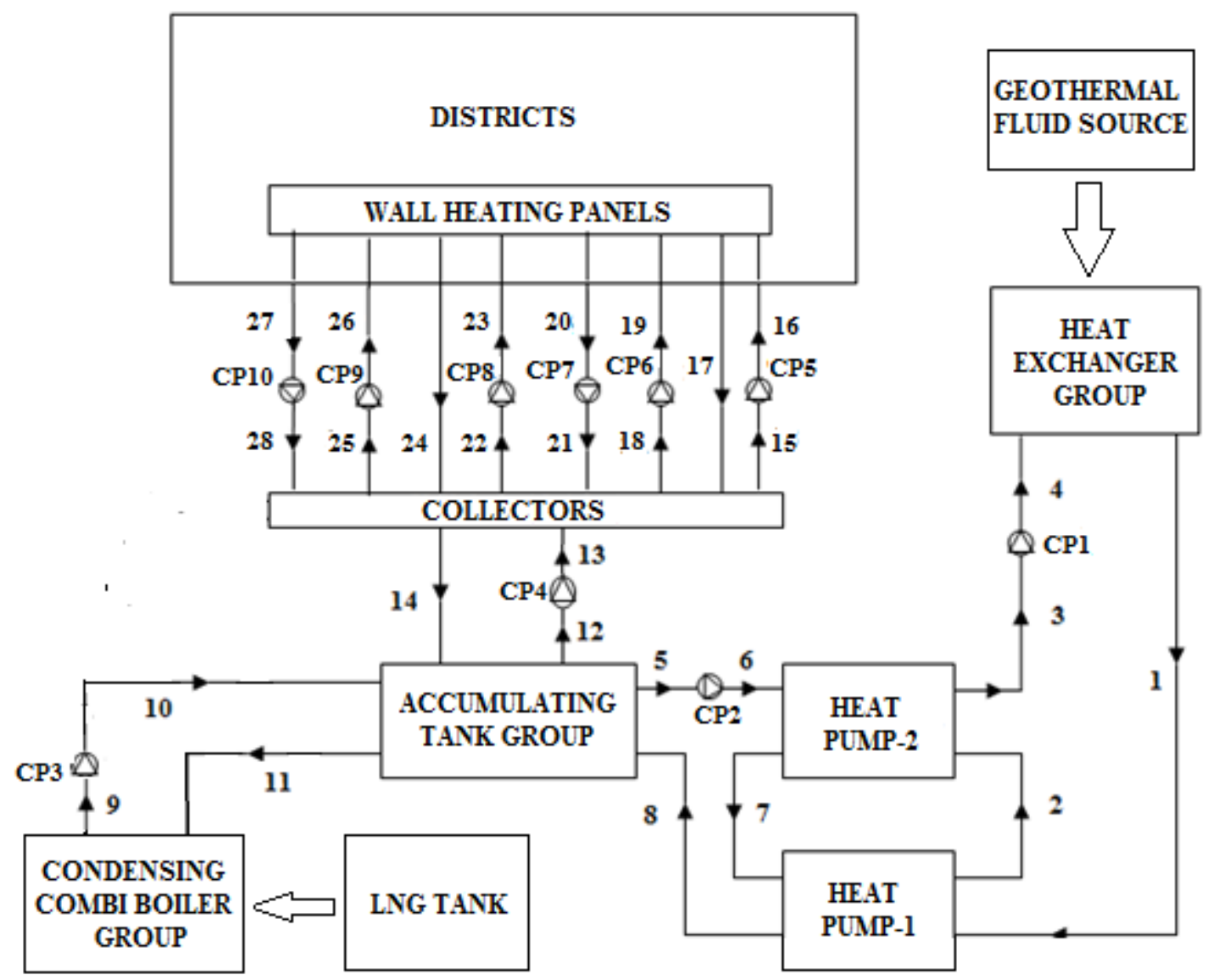

Figure 1:

The schematic representation of the Oylat Geothermal Heating System

In addition to this, the heat created by the condensing combi boiler (CCB) group by burning natural gas is transferred to the ATs via the CCB-AT cycle to provide extra heat for the districts in the coldest days of the year. All accumulated heat in the ATs is conducted to the district heating cycle (DHC) and increases the temperature of water in this cycle from nearly $53{ }^{\circ} \mathrm{C}$ to $60{ }^{\circ} \mathrm{C}$ and $73{ }^{\circ} \mathrm{C}$ to $80^{\circ} \mathrm{C}$ in cases of respectively heating by only geothermal energy and the hybrid configuration. Finally, water heat in the DHC is emitted to the districts by the wall panels. In all cycles, water is circulated by the circulating pumps (CPs). In current analysis of the system, these assumptions were made:

The ambient temperature and atmospheric pressure were taken as $7^{\circ} \mathrm{C}$ and 0.9 atm respectively.The fluid circulated in all cycles of the system was water.The specific heat capacity of water was taken as $4.186 \mathrm{~kJ} / \mathrm{kg}^{\circ} \mathrm{C}$. Independently, the exergy of natural gas and the products of combustion were calculated to be $\dot{E} x_{N G}=243 \mathrm{~kW}$ and $\dot{E} x_{\text {pof }}=9.049 \mathrm{~kW}$ respectively. The 
electricity consumption of the compressors in the HP1 and HP2 were $\dot{W}_{c o m p 1}=157 \mathrm{~kW}$ and $\dot{W}_{\text {comp } 2}=148 \mathrm{~kW}$. The heat losses of the heat exchangers in the geothermal fluid pool were negligible. In the system water pipes were insulated, therefore the heat losses in those were ignored. Heat losses in the compressors, condensers and evaporators of the HPs were taken into consideration $\left(\dot{Q}_{\text {loss, comp }} \neq 0, \dot{Q}_{\text {heating }} \neq 0\right.$ and $\left.\dot{Q}_{\text {cooling }} \neq 0\right)$. There were no heat losses in the throttling valves $\left(\dot{Q}_{\text {loss,exp }}=0\right)$. The refrigerant fluid in the HP cycles was R134a. Although the accumulating tanks were insulated, there were still heat losses $\quad\left(\dot{Q}_{\text {loss }, A T} \neq 0\right)$. The system lifespan was considered as 20 years with arepayment rate of $6 \%$, an escalation rate of $4 \%$ and an interest rate of 3\%. Annual and daily working periods of the system were assumed to be 180 days/year and 24 hours/day respectively.The HPs containing the compressors,condensers, throttling valves and evaporators had a single cost of 260000 euros including the costs of measurement and control equipments and software systems. In the HE group, there were 18 HEs made of stainless steel with a total cost of 102143 euros. In the AT group, there were 6 ATs in the system made of stainless steel and with a total cost of 31381 euros. The total storage capacity of these equipments was $30000 \mathrm{lt}$. In the CCB group, there were $8 \mathrm{CCBs}$ operated at $63 \%$ of maximum heating capacity of $150 \mathrm{~kW}$. The total cost of these equipments was 32143 euros. In each of CP1, CP3 and CP4 groups, there were 3 CPs each with $0.679 \mathrm{~kW}$ capacity, while in CP2 group, there were 2 CPs each with the same capacity. Each of individual CP5, CP6, CP7, CP8, CP9 and CP10 pumps has $1.564 \mathrm{~kW}$ capacity. The total cost of CPs was 10627 euros.The WHPs were made of cold-rolled sheet with a total length of $645 \mathrm{~m}$.

The cost of WHPs including ancillary items such as PPRC pipes with $25 \mathrm{~mm}$ and $20 \mathrm{~mm}$ diameters was 50000 euros.The total length of water pipes made of steel was assumed to be $1290 \mathrm{~m}$ with a unit cost of $32 \mathrm{euro} / \mathrm{m}$. Including auxiliary equipment, the total cost of those was calculated to be 53506 euros. The annual maintenance cost of the system was assumed to be 5000 euros.

\subsection{Energy Analysis of the System}

The mass of a substance passing through any cross sectional area per unit time is called mass flow rate and symbolized by $\dot{m}$. The mass flow rate for a particular control volume is given by Equation (1).

$$
\sum \dot{m}_{\text {in }} h_{\text {in }}=\sum \dot{m}_{\text {out }} h_{\text {out }}
$$

The energy balance of a steady state control volume is defined by Equation (2a) and (2b).

$$
\begin{array}{cl}
\text { (Net energy transfer rate in } & \text { (Net energy transfer rate out } \\
\text { by heat, work and mass) } & \text { by heat, work and mass) }
\end{array}
$$

which is a statement that represents the conversation of energy. The system's net energy change in total through a process corresponds with the difference of the total energy enters and the total energy exits from each other.

$$
\begin{gathered}
E_{\text {input }}-E_{\text {output }}=\Delta E_{\text {system }} \\
\dot{Q}+\sum \dot{m}_{\text {in }} h_{\text {in }}=\dot{W}+\sum \dot{m}_{\text {out }} h_{\text {out }}
\end{gathered}
$$


where $\dot{Q}=\dot{Q}_{\text {net,in }}=\dot{Q}_{\text {in }}-\dot{Q}_{\text {out }}$ is the net heat rate in, $\dot{W}=\dot{W}_{\text {net,out }}=\dot{W}_{\text {out }}-\dot{W}_{\text {in }}$ is the net work rate out and $\mathrm{h}$ is specfic enthalpy.

Neglecting small kinetic and potential energy changes and assuming no heat or work transmissions, the energy balance equation can be written as below.

$$
\sum \dot{m}_{\text {in }} h_{\text {in }}=\sum \dot{m}_{\text {out }} h_{\text {out }}
$$

For all system, Equation (4) can be written following energy conversation.

$$
\begin{gathered}
\dot{E}_{\text {in }, \text { sys }}=\dot{Q}_{H H V, N G}+\dot{Q}_{H E, \text { in }}+\dot{W}_{C C B, t o t}+\dot{W}_{\text {comp }, \text { tot }}+\dot{W}_{C P, t o t} \\
\dot{E}_{\text {out }, \text { sys }}=\dot{Q}_{W H P}+\dot{Q}_{\text {loss }} \\
\dot{Q}_{H H V, N G}+\dot{Q}_{H E, \text { in }}+\dot{W}_{C C B, t o t}+\dot{W}_{\text {comp }, \text { tot }}+\dot{W}_{C P, t o t}=\dot{Q}_{W H P}+\dot{Q}_{\text {loss }}
\end{gathered}
$$

The coefficient of performance for all system can be calculated by Equation (7).

$$
C O P_{H, s y s}=\frac{\dot{Q}_{W H P}}{\dot{W}_{C C B, t o t}+\dot{W}_{c o m p, t o t}+\dot{W}_{C P, t o t}}
$$

For each component of the system, the equations for the energy analysis are given in Table 1 (Akbulut et. al, 2016).

\subsection{Exergy Analysis of the System}

Exergy (availability) is defined as the most useful work for a system in a certain state. The exergy is the system's asset andalsothe term of 'exergy' can be described as theability of working. The exergy of a system in the state of balance with its environment is zero. This case is called 'the dead state of the system' (Akbulut et. al, 2016). Exergy analysis is a convenient method to explain the ambient influence of energy sourceusage and to improve the aim of more effective energy-source utilization. Because it provides a determination of the points, sorts and correct quantities of losses. In addition to this, exergy analysis expresses if and how much it is achievable to configurate more productive energy systems by decreasinginefficiencies (Kanoglu et all, 2012).A system's total exergy is comprised of four main elements: kinetic, chemical, potential, and physical. Total exergy is given by Equation (8).

$$
E x=E x^{P H}+E x^{C H}+E x^{K E}+E x^{P E}
$$

In this paper, physical exergy is only taken into account.Physical exergy what is because of the abberation of the pressure and temperature of the system from its environment comprises of:thermal exergy related to the temperature of the system and mechanical exergy related to the pressure of the system. In a certain thermodynamic condition at pressure $\mathrm{P}$ and temperature $\mathrm{T}$, the mechanical exergy must be determined by following the isothermal linefrom case $\left[\mathrm{T}_{0}, \mathrm{P}\right]$ to 
case $\left[\mathrm{T}_{0}, \mathrm{P}_{0}\right]$ at $\mathrm{T}_{0}$ while the thermal exergy can be determined by following the isobaric line from condition $[\mathrm{T}, \mathrm{P}]$ to condition $\left[\mathrm{T}_{0}, \mathrm{P}\right]$ at $\mathrm{P}$. Physical exergy is used to calculate the efficiency of the heat pump, therefore it is composed of two elements; as mechanical exergy and thermal exergy.

The value of physical exergy per mass is indicated by $\psi$ for an open system and by $\varnothing$ for a closed system. The ambient condition is denoted by zero indices (0). Exergy per unit mass in a closed system is calculated by Equation (9) while the exergy in an open system with a steady state flow is determined by Equation (10).

$$
\begin{gathered}
\varnothing=\left(u-u_{0}\right)+P_{0}\left(V-V_{0}\right)-T_{0}\left(s-s_{0}\right) \\
\psi=\left(h-h_{0}\right)-T_{0}\left(s-s_{0}\right)
\end{gathered}
$$

The exergy balance equation for all system can be given as below.

$$
\dot{E} x_{\text {in }}-\dot{E} x_{\text {out }}=\dot{E} x_{D}
$$

(Net exergy transferby heat, work or mass) (Exergy destruction rate) or

$$
\dot{E} x_{\text {heat }}-\dot{E} x_{\text {work }}+\dot{E} x_{\text {mass, }, \text { in }}-\dot{E} x_{\text {mass }, \text { out }}=\dot{E} x_{D}
$$

Following this, exergy rate balance equation can also be given as

$$
\sum \dot{Q}_{k}\left(1-\frac{T_{0}}{T_{k}}\right)-\dot{W}+\sum \dot{m}_{\text {in }} \psi_{\text {in }}-\sum \dot{m}_{\text {out }} \psi_{\text {out }}=\dot{E} x_{\text {dest }}
$$

Here, $\dot{W}$ is the work rate and $\dot{Q}_{k}$ is the rate of heat passing through the boundry at location $k$ and temperature $T_{k}$ (Akbulut et. al, 2016).

For heat pump circuits, exergy is utilized to assess the irreversibility measure of the activity. Therefore, the aim of an optimization work is to minimise the exergy destruction in each element of the heat pump. The Carnot efficiency given by Equation (13) is used to express exergy transmissions during the various processes of the heat pump circuit, where $T_{0}$ commonly denotes the environmental temperature and $\bar{T}_{s o}$ subtends to the mean source temperature, Equation (14). The log mean temperature is typically used. The use of this format of the Carnot efficiency allows to assess exergy as the ideally recoverable mechanical work from a quantity of thermal energy $\dot{Q}$ (Equation (15)).

$$
\begin{gathered}
\eta_{\text {Carnot }}=\left|1-\frac{T_{0}}{\bar{T}_{\text {so }}}\right| \\
\bar{T}_{\text {so }}=\frac{T_{\text {in }}-T_{\text {out }}}{\ln \left(\frac{T_{\text {in }}}{T_{\text {out }}}\right)} \\
\dot{E} x=\dot{Q} \cdot \eta_{\text {Carnot }}
\end{gathered}
$$


Exergetic efficiency is the generated exergy ratio to the supplied exergy for the system, which is the electrical power taken by the compressor (Equation (16)). Mechanical work and electrical energy are regarded as mere sorts of exergy. The power wasted by the ancillaries is also considered in the calculation of exergy efficiency.

$$
\eta_{\text {ex-heating }}=\frac{\dot{E} x_{\text {heating }}}{\dot{W}_{\text {comp }}+\dot{W}_{\text {ancillaries }}}
$$

Developing an actual heat pump circuit comprises of minimising the destruction of exergy throughout the four operations of the thermodynamic cycle, particularly throughout compression. An exergy analysis allows of evaluating each element in where the development may be estimated. The theory based formulation of exergy destruction for each process is indicated by the equations below (Eqs. (17) - (20)). The destructed exergy rate in the condenser and the evaporator is the difference of the exchanged exergy rate between the refrigerant and the source. In the expansion period (Eq. (19)), there is an exergy recovery; the value of exergy destruction is negative. Temperatures and pressures at each point of the refrigeration cycle weredetermined during the numerical calculations. Enthalpy and entropy values were then determined using thermodynamic tables (Byrne and Ghoubali, 2019).

$$
\begin{gathered}
\dot{E} x_{\text {des-comp }}=\dot{W}-\dot{m} \cdot\left[\left(h_{\text {out }}-h_{\text {in }}\right)-T_{0}\left(s_{\text {out }}-s_{\text {in }}\right)\right] \\
\dot{E} x_{\text {des-cond }}=\dot{m} \cdot\left[\left(h_{\text {in }}-h_{\text {out }}\right)-T_{0} \cdot\left(s_{\text {in }}-s_{\text {out }}\right)\right]-\dot{Q}_{\text {heating }} \cdot\left|1-\frac{T_{0}}{\bar{T}_{\text {so }}}\right| \\
\dot{E} x_{\text {des-exp }}=\dot{m} \cdot\left[-T_{0} \cdot\left(s_{\text {in }}-s_{\text {out }}\right)\right] \\
\dot{E} x_{\text {des-ev }}=\dot{Q}_{\text {cooling }} \cdot\left|1-\frac{T_{0}}{\bar{T}_{\text {so }}}\right|-\dot{m} \cdot\left[\left(h_{\text {out }}-h_{\text {in }}\right)-T_{0}\left(s_{\text {out }}-s_{\text {in }}\right)\right]
\end{gathered}
$$

For all of the investigated system in this study, exergy balance equation:

$$
\begin{gathered}
\dot{Q}_{W H P}\left(1-\frac{T_{0}}{T_{D}}\right)+\dot{W}_{C P, t o t}+\dot{W}_{c o m p, t o t}+\dot{W}_{C C B, t o t}-\left[\dot{E} x_{N G}+\dot{Q}_{H E, i n}\left(1-\frac{T_{0}}{T_{g f}}\right)\right] \\
=\dot{E} x_{d e s, s y s}
\end{gathered}
$$

The ratio of product exergy to fuel exergy is the exergy efficiency. The product exergy refers to ambitioned result (denoted with regard to exergy) produced by the considered system. The fuel exergy refers to the resources (denoted with regard to exergy) consumed to supply the product exergy. Then, without being limited to fossil fuels, the term 'fuel exergy' refers to the exergetic sources utilized to operate the process analysed.

$$
\eta_{I I}=\frac{\dot{E} x_{N G}+\dot{Q}_{H E, \text { in }}\left(1-\frac{T_{0}}{T_{g f}}\right)}{\dot{Q}_{W H P}\left(1-\frac{T_{0}}{T_{D}}\right)-\dot{W}_{C P, t o t}+\dot{W}_{c o m p, t o t}+\dot{W}_{C C B, t o t}}
$$


Table 1. The balance equations of energy and exergy for the entire system and its units.

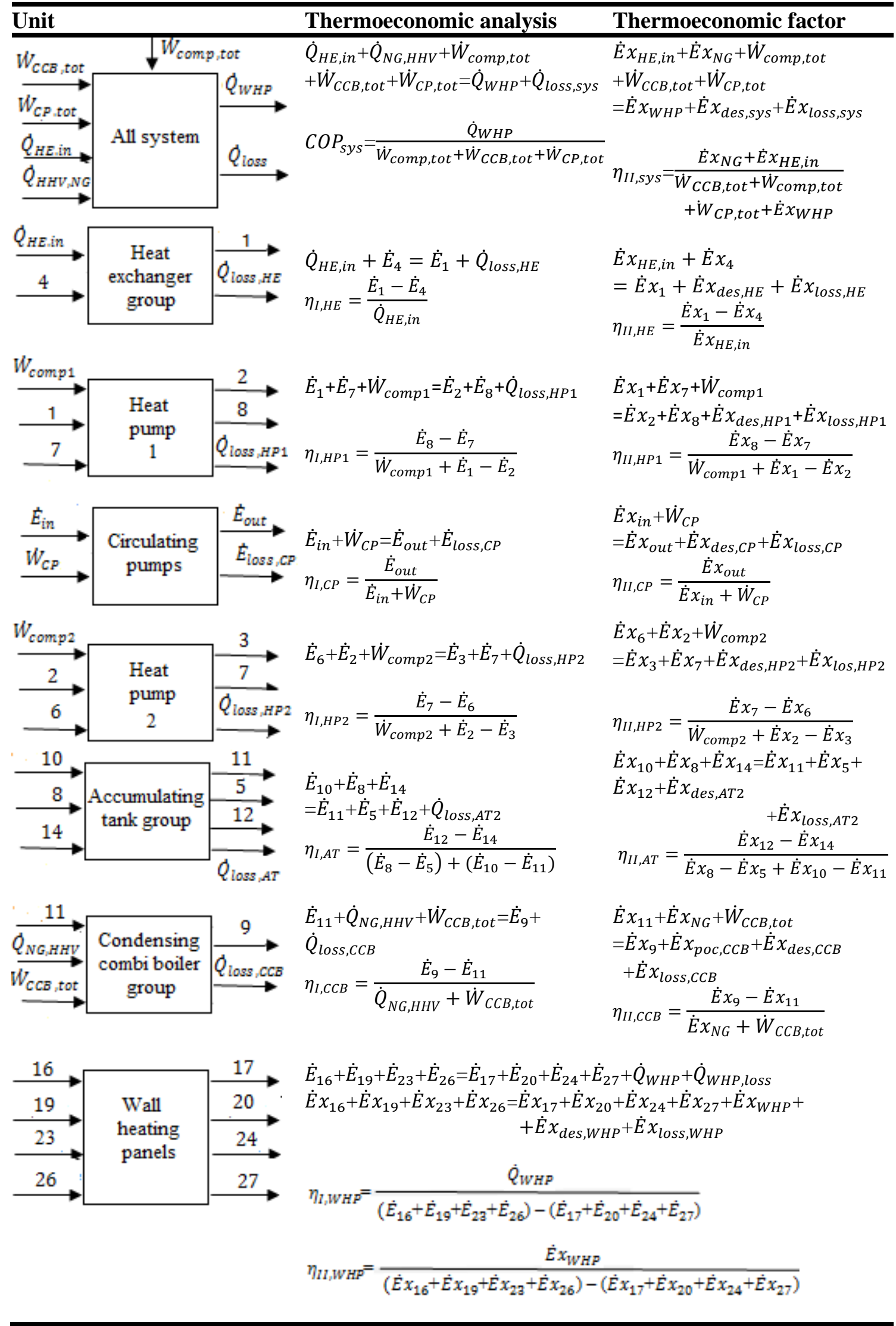


Allowing for the efficiency of the CCBs, compressors and pumps in accordance with product/fuel principle, exergy efficiency is determined by Equation (22).

For the exergy analysis of each component in the system, the equations given in Table 1 are used (Akbulut et. al, 2016).

\subsection{Thermoeconomic Analysis of the System}

The unit exergy cost (i.e., exergy cost) is the energy consumed by a system to generate a unit of exergy and is determined by computing the investment and operational costs besides the wasted fuel cost. For the thermoeconomic analysis, the system periodforthe generation of product and the product volume at the end of this period should be taken into account. Cost stems from all sources to generate a product must be regarded and assessed as standby or variable costs. Standby costs consist of start-up costs, for instance system installation, and initial investment, insurance, amortisation, taxes and other costs. Maintenance charges also take place in this class. These standby costs impact the amount of production notably. The variable costs consist of spendings such asescalationandraw material fees,fuel, energy and employee fees. The variable costs directly impact the volume of production. As a first step to analyze a system, initial investment costs must be determined. The initial investment costs differ from the variable expenditures and are only worked out once over the operational life of the system. Thus, for obtainment of adequate funds to initiate the system, different configurations are necessary.In this study, to carry out the thermodynamic analysis of the system, SPECO (Specific exergy costing) method was used.

SPECO is a thermoeconomic analysis approach generated by Lazzaretto and Tsatsaronis, (2006) and constituded of three steps:

- The determination of the exergy quantities enters and exits each component of the system.

- Calculating the exergy fluxes defined asproductand fuel for any element; and

- The cost determination for the found exergy quantities.

In the thermodynamic analysis of the system, the unit exergy cost (c) for input fluxes of a component is supposed known. Therefore, the ' $\mathrm{k}$ ' component's indeterminate value to be computed with a fiscal formulae can be given as the unit produced exergy cost if the heat and work generation of the component are known. To determine these costs, using formula is typically required.

In this context, the exergy flow $(\dot{E} x)$ can be definedas the total exergy flux cost $(\dot{C})$;

$$
\dot{C}=c \dot{E} x
$$

In calculating the system exergy cost, each unit in the system is considered individually. Cost balance formula for ' $k$ ' elements can be expressed as follows. The cost flow balance can be defined by Equation (24) with identifying input and output cost per unit.

$$
\begin{gathered}
\sum_{\text {in }} c_{\text {in }} \dot{E} x_{\text {in }}+\dot{Z}=\sum_{\text {out }} c_{\text {out }} \dot{E} x_{\text {out }} \\
\sum C_{e, k}+C_{w, k}=C_{q, k}+\sum_{\text {out }} C_{i, k}+Z_{k}
\end{gathered}
$$


Where $\dot{Z}$ denotes the levelized cost and is the total of the investment and operating costs.

$$
\dot{Z}=\dot{Z}^{C I}+\dot{Z}^{O M}
$$

The expense source of a unit is categorised in two classes. The first consists of the payments of exergy such as the initial investment cost, the maintenance and repair cost and operational costs). The second class includes the exergy loss and destruction. To enhance the productivity of a system element is, the productivity of both elements must importantly be known. As assessing the component, the more efficient determinant in terms of the exergy cost denotes where developments can be occured to take the most effective results. The thermoeconomic factors permit this indication; those factors can be determined by the costs obtained by the use of Equation (26) independently of exergy and by Equation (27) which expresses thedestructioncost of exergy the system. The exergy factor can be obtained by combining the costs of exergy destruction in one equation (Equation 28).

$$
\begin{gathered}
\dot{C}_{\text {destruction }}=c_{\text {fuel }} \dot{E} x_{\text {destruction }} \\
f_{C}=\frac{\dot{Z}}{\dot{Z}+\dot{C}_{\text {destruction }}}
\end{gathered}
$$

A thermoeconomic computation for each main components denotes that the component should be switched to decrease the first investment costs to retrench expenses for the entire system (declining the destruction of exergy). The escalated efficiency of a component may be a small value of the component even if the initial investment cost of the component rises. Therefore, even if the capital and operational expenditures escalate, the component may be operated with a higher efficiency. Besides, a comparatively high thermoeconomic factor value denotes that the first investment cost for the unit is comparatively high depending on the exergy efficiency of the unit or component, i.e., monetary expenses of the component mainly stem from investment and operational expenditures. Then, to raise the efficiency of the component, e.g., to reduce the difference of temperature in heat flux, an enlargement on the surface or using more expensive component which is more efficent will not be reasonable. The characteristically thermoeconomic values of $\% 70$ for pumps, between $\% 35$ and $\% 70$ for compressors and $\% 55$ for heat exchangers are typical (Akbulut et. al, 2016).

\subsubsection{Capital Recovery Factor (CRF)}

The present amount of an annual cost is defined as the fiscal value for a given process and the effective rate of interest is determined by the use of Equation (29). ' $n$ ' is the estimated system lifespan or its units.

$$
\frac{P}{A}=\frac{(1+i)^{n}-1}{i(1+i)^{n}}
$$

Also, the capital recovery factor is used in calculating ' $n$ ' equal ' $p$ ' pays and is expressed as this value (Akbulut et. al, 2016). 


$$
C R F=\frac{(1+i)^{n}-1}{i(1+i)^{n}}
$$

\subsubsection{Inflation and Escalation}

Inflation is the escalation in price of a certain service or product without any enhancement in the quality of aservice or product (or without any enhancement in the same ratio). If inflation actualises, the costs change (Akbulut et. al, 2016).Escalation is a variation depending on some causes such as technological development, reduced production, resource depletion and demand growth or diminishment. While the actual value of escalation is independent of inflation, the observed (nominal) value of escalation is yearly change of costs and is impacted by inflation and the actualvalue of escalation (Akbulut et. al, 2016).

\subsubsection{Levelling and Levellized Cost}

If cost escalation is realized to expense over ' $n$ ' years, an irregular series with the escalation will be $\left(1+r_{n}\right)$ times higher than the preceding year's escalation. This leads to a rising geometric series of expenses. The term called CELF (Constant escalation levelling factor) is used for defining the relation between equivalent yearly payments and regarded as the leveling number at the starting of the first year. The CELF is subject to the nominal escalation value and the effective interest rate and is determined by Equation (32) using the price correction factor, Equation (31) (Akbulut et. al, 2016).

$$
\begin{gathered}
k=\frac{1+r_{n}}{1+i} \\
C E L F=\frac{k\left(1-k^{n}\right)}{1-k}
\end{gathered}
$$

The cost given to value using the defined interest rate $\left(r_{i}\right)$ and levelling factor is calculated by $(A)$, Equation (33). The cost given to a value is found by using Equation (34) (Akbulut et. al, 2016).

$$
\begin{gathered}
A=\frac{C E L F}{1+r_{i}} \\
\dot{Z}=A\left[\frac{\text { Initial investment cost }}{\text { System lifespan } x \text { working hour per annum }}\right. \\
\left.+\frac{\text { Electricity }+ \text { Maintenance cost }}{\text { Working hour per annum }}\right]
\end{gathered}
$$

\subsubsection{Thermoeconomic analysis of the whole system}

The thermoeconomic balance of the whole system is indicated by Equation (35).

$$
\dot{C}_{Q, N G}+\dot{C}_{Q, H E}+\dot{C}_{W, C C B}+\dot{C}_{W, c o m p}+\dot{C}_{W, C P}+\dot{Z}_{s y s t e m}=\dot{C}_{Q, D}
$$


Table 2. Thermoeconomic analysis and thermoeconomic factor equations.

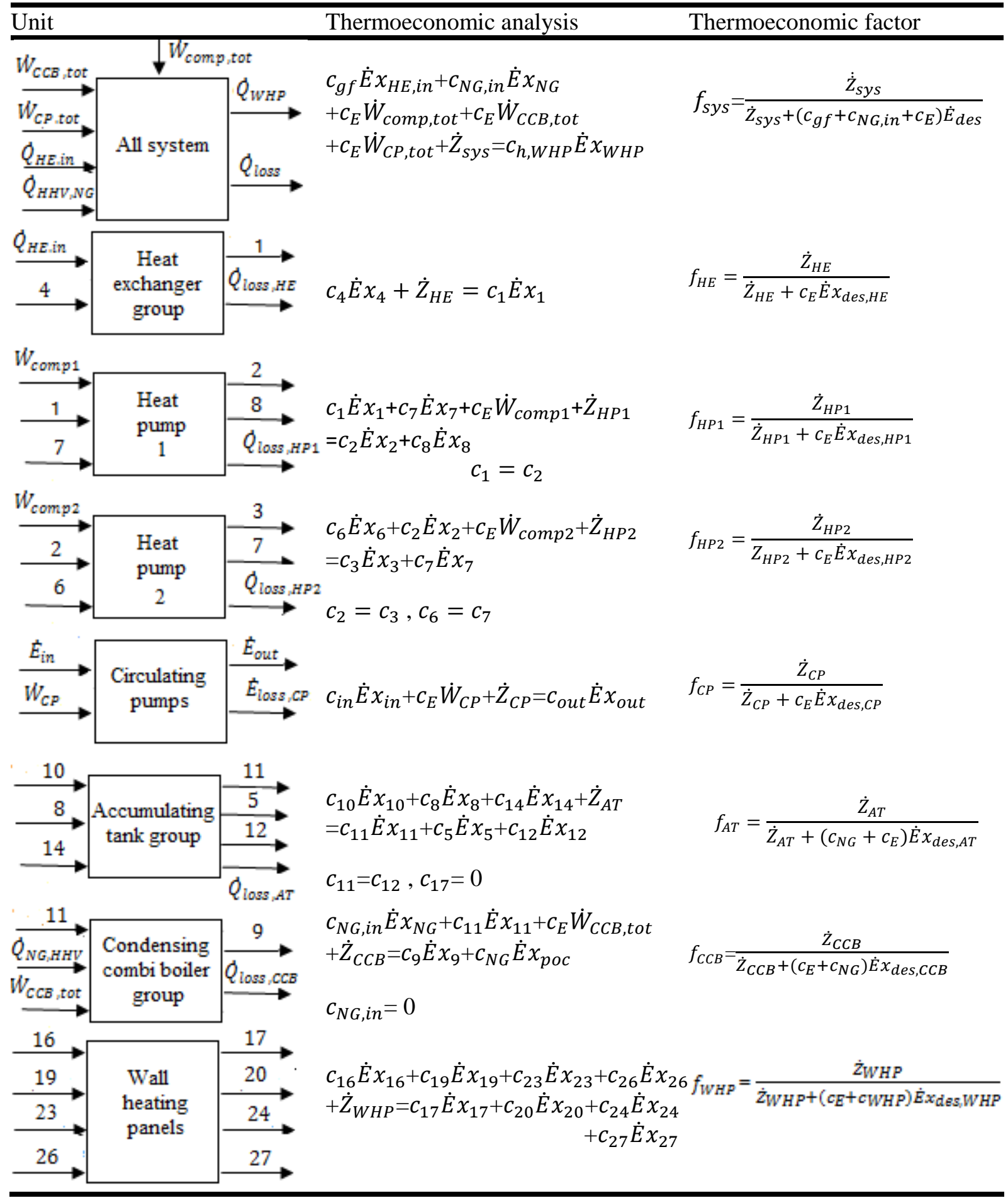

The thermoeconomical value that stems from the operation and configuration of the system is computed as a financial value, Equation (36).

$$
\dot{Z}_{\text {system }}=\dot{Z}_{\text {system }}^{\text {production }}+\dot{Z}_{\text {system }}^{\text {operation }}+\dot{Z}_{\text {system }}^{\text {waste }}
$$


Yamankaradeniz N., Sahmerdan O.: Energy Exergy Analysis. of a Geothermal Htg. Sys.

The thermoeconomic factor is found by Equation (37).

$$
f_{C, \text { system }}=\frac{\dot{Z}_{\text {system }}}{\dot{Z}_{\text {system }}+\dot{C}_{\text {dest }, \text { system }}}
$$

For the thermoeconomic analysis of the system and each components with specified boundaries and control volumes, the equations given in Table 2 are used (Akbulut et. al, 2016)

\section{RESULTS AND DISCUSSION}

The system in this study is investigated in three parts. In the first part, energy analysis and efficiency take place. The second part includes exergy analysis and efficiency while the third part contains thermoeconomic analysis and thermoeconomic factor. The system configuration comprises of four thermodynamic cycles and 16 components as mentioned in the second part of the study. However, for all circulating pumps, the total values are given in this part of the work. The point energy/exergy values of the system are presented in Table 3 . The energy loss and efficiency of the components in the system are given in Table 4.

Table 3. Point energy and exergy values of the system.

\begin{tabular}{ccccccc}
\hline Point & $\mathbf{\text { m }}(\mathbf{k g} / \mathbf{s})$ & $\mathbf{T}\left({ }^{\circ} \mathbf{C}\right)$ & $\mathbf{h}(\mathbf{k J} / \mathbf{k g})$ & $\mathbf{s}(\mathbf{k J} / \mathbf{k g K})$ & $\dot{\mathbf{E}}(\mathbf{k W})$ & $\dot{\mathbf{E} x}(\mathbf{k W})$ \\
\hline $\mathbf{1}$ & 25.00 & 30 & 125.790 & 0.4369 & 3144.750 & 93.650 \\
$\mathbf{2}$ & 25.00 & 25 & 104.890 & 0.3692 & 2622.250 & 57.650 \\
$\mathbf{3}$ & 25.00 & 20 & 83.960 & 0.2966 & 2099.000 & 30.000 \\
$\mathbf{4}$ & 25.00 & 20 & 83.960 & 0.2966 & 2099.000 & 30.000 \\
$\mathbf{5}$ & 30.55 & 50 & 209.330 & 0.7038 & 6395.031 & 383.494 \\
$\mathbf{6}$ & 30.55 & 50 & 209.330 & 0.7038 & 6395.031 & 383.494 \\
$\mathbf{7}$ & 30.55 & 55 & 230.230 & 0.7675 & 7033.526 & 473.708 \\
$\mathbf{8}$ & 30.55 & 60 & 251.130 & 0.8312 & 7672.021 & 570.704 \\
$\mathbf{9}$ & 9.016 & 80 & 334.910 & 1.0753 & 3019.548 & 307.562 \\
$\mathbf{1 0}$ & 9.016 & 80 & 334.910 & 1.0753 & 3019.548 & 307.562 \\
$\mathbf{1 1}$ & 9.016 & 60 & 251.130 & 0.8312 & 2264.188 & 168.427 \\
$\mathbf{1 2}$ & 47.220 & 80 & 334.910 & 1.0753 & 15814.450 & 1611.656 \\
$\mathbf{1 3}$ & 47.220 & 80 & 334.910 & 1.0753 & 15814.450 & 1611.656 \\
$\mathbf{1 4}$ & 47.220 & 73 & 305.550 & 0.9898 & 14428.071 & 1355.723 \\
$\mathbf{1 5}$ & 4.417 & 80 & 334.910 & 1.0753 & 1479.297 & 150.755 \\
$\mathbf{1 6}$ & 4.417 & 80 & 334.910 & 1.0753 & 1479.297 & 150.755 \\
$\mathbf{1 7}$ & 4.417 & 73 & 305.550 & 0.9898 & 1349.614 & 126.815 \\
$\mathbf{1 8}$ & 17.668 & 80 & 334.910 & 1.0753 & 5917.189 & 603.022 \\
$\mathbf{1 9}$ & 17.668 & 80 & 334.910 & 1.0753 & 5917.189 & 603.022 \\
$\mathbf{2 0}$ & 17.668 & 73 & 305.550 & 0.9898 & 5398.457 & 507.262 \\
$\mathbf{2 1}$ & 17.668 & 73 & 305.550 & 0.9898 & 5398.457 & 507.262 \\
$\mathbf{2 2}$ & 7.465 & 80 & 334.910 & 1.0753 & 2500.103 & 254.786 \\
$\mathbf{2 3}$ & 7.465 & 80 & 334.910 & 1.0753 & 2500.103 & 254.786 \\
$\mathbf{2 4}$ & 7.465 & 73 & 305.550 & 0.9898 & 2280.930 & 214.326 \\
$\mathbf{2 5}$ & 17.668 & 80 & 334.910 & 1.0753 & 5917.189 & 603.022 \\
$\mathbf{2 6}$ & 17.668 & 80 & 334.910 & 1.0753 & 5917.189 & 603.022 \\
$\mathbf{2 7}$ & 17.668 & 73 & 305.550 & 0.9898 & 5398.457 & 507.262 \\
$\mathbf{2 8}$ & 17.668 & 73 & 305.550 & 0.9898 & 5398.457 & 507.262 \\
\hline
\end{tabular}


According to this data, it can be stated that the most energy loss actualised in the accumulating tanks while the lowest energy loss actualised in the heat exchangers situated in the geothermal fluid pool. The total energy losses were $645.971 \mathrm{~kW}$ in the accumulating tanks, $254.910 \mathrm{~kW}$ in the condensing combi boilers, $41.005 \mathrm{~kW}$ in the Heat Pump 1, $32.755 \mathrm{~kW}$ in the Heat Pump 2 and $36.379 \mathrm{~kW}$ in the WHS panels. The first law efficiencies of the system components are also given in Table 4. According to this table, the less efficient components were thecondensing combi boilers at $74.7 \%$ and the accumulating tanks at $68.2 \%$. Therefore, these units should be enhanced.

Table 4. Energy loss and efficiency of the system and its components.

\begin{tabular}{lcccc}
\hline Components & $\dot{\mathbf{E}}_{\text {input }}(\mathbf{k W})$ & $\dot{\mathbf{E}}_{\text {output }}(\mathbf{k W})$ & $\dot{\mathbf{E}}_{\text {loss }}(\mathbf{k W})$ & $\boldsymbol{\eta}_{\mathbf{I}}(\%)$ \\
\hline All System & 2377.873 & 1350 & 1027.873 & 56.77 \\
Heat pump 1 & 10335.276 & 10294.271 & 41.005 & 93.96 \\
Heat pump 2 & 9165.281 & 9132.526 & 32.755 & 95.12 \\
$\begin{array}{l}\text { Condensing combi } \\
\text { boiler group }\end{array}$ & 3274.458 & 3019.548 & 254.91 & 74.76 \\
$\begin{array}{l}\text { Heat exchangers } \\
\text { Accumulating tank }\end{array}$ & 3144.750 & 3144.750 & 0 & 100 \\
group & 25119.64 & 24473.669 & 645.971 & 68.21 \\
$\begin{array}{l}\text { Circulating pumps } \\
\text { Wall heating panels }\end{array}$ & 53955.574 & 53938.721 & 16.853 & 99.96 \\
\hline
\end{tabular}

Each of condensing combi boilers are operated at $63 \%$ of maximum capacity at $150 \mathrm{~kW}$. In this case more heat conveyed to the accumulating tanks from condensing combi boilers and the heat amount not utilized stored in the accumulating tanks. This led to the less efficiency of theaccumulating tanks. In case of using 7 combi boilers, the efficiency of the accumulating tank group reaches at $71 \%$ whilst the the efficiency of the CCB group decreases to $72 \%$ which is the balance condition between the combi boiler and accumulating tank group. Because, decreasing the number of the combi boilers more increases the efficiency of the accumulating tank group but declines the efficiency of the CCB group.The equations used to determine the input exergy amount, the output exergy amount, the exergy destruction amount and the second law efficiency of the system and its components are given in Table 1. The values in Table 5 are based on these equations.

Table 5. Exergy loss and efficiency of the system and its components.

\begin{tabular}{lcccc}
\hline Components & $\dot{\mathbf{E}} \mathbf{x}_{\text {input }}(\mathbf{k W})$ & $\dot{\mathbf{E}} \mathbf{x}_{\text {output }}(\mathbf{k W})$ & $\begin{array}{c}\dot{\mathbf{E}} \mathbf{x}_{\text {dest }} \\
(\mathbf{k W})\end{array}$ & $\boldsymbol{\eta}_{\text {II }}(\boldsymbol{\%})$ \\
\hline All System & 1150.497 & 574.555 & 575.942 & 49.93 \\
Heat pump 1 & 724.358 & 628.354 & 856.499 & 17.28 \\
Heat pump 2 & 589.144 & 503.708 & 826.666 & 14.94 \\
$\begin{array}{l}\text { Condensing combi } \\
\text { boiler group }\end{array}$ & 1167.014 & 316.611 & 850.403 & 13.93 \\
$\begin{array}{l}\text { Heat exchangers } \\
\text { Accumulating tank }\end{array}$ & 140.254 & 93.650 & 46.604 & 57.73 \\
group & 2233.989 & 2163.567 & 70.422 & 78.42 \\
$\begin{array}{l}\text { Circulating pumps } \\
\text { Wall heating panels }\end{array}$ & 4249.186 & 4237.765 & 11.421 & 99.73 \\
\hline
\end{tabular}

By examining Table 5, the exergy destruction with the highest rate occurred in the heat pump 1 with $856,499 \mathrm{~kW}$ while the lowest exergy destruction rates occured in the circulating 
pumps and the heat exchanger group as $11.421 \mathrm{~kW}$ and $46.604 \mathrm{~kW}$, respectively. According to this system analysis associated with exergy efficiency, the highest exergy efficiency was obtained in the circulating pumps with $99.73 \%$. Compatibly with the exergy destruction rates, the lowest exergy efficiencies was detected in the condensing combi boiler group, heat pump 2 and heat pump 1 with $13.93 \%, 14.80 \%$ and $16.90 \%$, respectively. Especially, the high electricity consumption of the condensing combi boiler group impacted significantly the efficiency of this unit and the all system. Meanwhile, the less exergetic efficiency of the heat pumps was caused of the high compressor powers of these devices and the less temperature difference in cooled water. On the other hand, the high exergy destruction rates in the heat pumps stemmed from the high pressure differences in the compressors.

Using the equations in Table 2, the thermoeconomic analysis results of the system and each components are presented in Table 6. In this part of the study, three main parameters were considered as the economic variables. These are the levellized cost, exergy destruction cost and thermoeconomic factor. For the whole system, those were calculated as $45.164 € / \mathrm{h}, 411.242 € / \mathrm{h}$ and $9.8 \%$ respectively.In Table 6, the exergy cost distributions of the system components are also presented. The exergy cost of the heat pump 1, heat pump 2, condensing combi boiler group, accumulating tank group, all of circulating pumps and wall heating panels were $115.596 € / \mathrm{h}, 111.531 € / \mathrm{h}, 128.821 € / \mathrm{h}, 19.916 € / \mathrm{h}, 1.608 € / \mathrm{h}$ and $33.555 € / \mathrm{h}$ respectively.

According to Table 6, the thermoeconomic factor was $11 \%$ and $\% 8$ for the heat pump 1 and heat pump 2 while it was $7.9 \%, 5 \%, 43.73 \%$ and $12.704 \%$ for the condensing combi boiler group, accumulating tank group, circulating pumps and wall heating panels respectively. In the system, the lowest thermoeconomic factor values were obtained for the accumulating tank group, condensing combi boiler group, heat pump 2 and heat pump 1. To increase the thermoeconomic factor values of those elements, the exergy losses and exergy costs in those components should be decreased.

Table 6. Thermoeconomic results of the system and its components.

\begin{tabular}{lccc}
\hline Components & $\dot{\boldsymbol{Z}}(\boldsymbol{\epsilon} / \mathbf{h})$ & $\dot{\boldsymbol{C}}(\boldsymbol{\epsilon} / \mathbf{h})$ & $\boldsymbol{f}(\boldsymbol{\%})$ \\
\hline All System & 45.164 & 411.242 & 9.8 \\
Heat pump 1 & 15.191 & 115.596 & 11.00 \\
Heat pump 2 & 10.040 & 111.531 & 8.00 \\
$\begin{array}{l}\text { Condensing combi } \\
\text { boiler group }\end{array}$ & 11.085 & 128.821 & 7.90 \\
Heat exchangers & & & \\
Accumulating tank & 1.022 & 0 & 100 \\
group & 1.183 & 19.916 & 5 \\
Circulating pumps & 1.757 & 1.608 & 43.73 \\
Wall heating panels & 4.883 & 33.555 & 12.704 \\
\hline
\end{tabular}

A comparison work between current findings and those of Ebadollahi et al. (2019) and Ghaebi et al. (2018) are conducted. In this context, comparison results are presented from energy, exergy and thermoeconomic standpoints. Firstly, a multigeneration system based on geothermal energy and utiling cold energy of LNG analyzed by Ebadollahi et al. (2019) is addressed and the results of this current study are compared with those of it in accordance with the normal operating conditions of both system. The heating capacity of the current system outperforms that of Ebadollahi et al. (2019) whose heating capacity is only $334.8 \mathrm{~kW}$. As mentioned before, the overall energy and exergy efficiencies of the current system are $56.77 \%$ and $49.93 \%$ respectively. Thermodynamically, the system investigated in this paper has higher overall both thermal and exergy efficiencies than those of Ebadollahi et al. (2019) with respectively $18.44 \%$ and $21.02 \%$. Hence, the current system is more efficient than that Ebadollahi et al. (2019) from thermodynamic standpoint.However, the system studied by 
Ebadollahi et al. (2019) outperforms the current system thermoeconomicallysince its nearly 8 times less amount of exergy destruction cost.Secondly, the system assessed by Ghaebi et al. (2018) is taken into consideration to be compared with this current system from thermodynamic and thermoeconomic viewpoints. The system they analyzed is a trigeneration system utilising geothermal energy and cold energy of LNG. Both systems are compared with each other according to their normal operating conditions. The overall thermal efficiency of the system studied by Ghaebi et al. (2018) is $29.15 \%$ higher than the current system by $85.12 \%$, while its exergetic efficiency is $31.41 \%$ less than the current system by $18.52 \%$. Although the higher thermal efficiency of the system that of Ghaebi et al. (2018), its heating output is only $35.3 \mathrm{~kW}$. To this data, the current system is exergetically more efficient than that of Ghaebi et al. (2018) and generates more heat power. However, the annual exergy destruction cost of the system studied in this paper is approximately 3 times higher than that of Ghaebi et al. (2018) whose yearly exergy destruction cost is 103.529 \$/year.

Table 7. Comparison of the present system with that of Ebadollahi et al. And Ghaebi et al.

\begin{tabular}{lccc}
\hline Parameters & Current system & Ebadollahi et al. & Ghaebi et al. \\
\hline Heating capacity $(\mathbf{k W})$ & 1350 & 334.80 & 35.30 \\
Overall thermal efficiency (\%) & 56.77 & 38.33 & 85.92 \\
Overall exergetic efficiency (\%) & 49.93 & 28.91 & 18.52 \\
Overall exergy destruction cost & 332204.91 & 43004 & 103529 \\
(\$/year) & & & \\
\hline
\end{tabular}

In the light of this information, it can be said that the total exergy desruction cost of the system is notably high by $332204.914 \$$ year $(1 €=1.121 \$$ and the current system is operated in the hybrid mode for only 1 month per year). This stems from the high exergy destruction rates in the heat pumps and CCB group. The reason of the high exergy destruction rates in the heat pumps is the high specific entropy difference between inlet and outlet points of the compressors belong to these heat pumps. In optimization works, heat pumps with less exergy destruction rates and costs can be designed by specifying the allowable low and high pressure values of these heat pumps closer to each other.As to CCBs, we can say that the high exergy destruction rate in these equipment occurs because of that a major of the fuel exergy is not conducted to the heated water circulated between CCBs and ATs. By increasing the amount of heated water in CCBs, the exergy destruction rate and so the exergy destruction cost in this unit can be decreased.

\section{CONCLUSIONS}

In this paper, the main objective was to conduct the thermodynamic andthermoeconomic analysis of natural gas assisted geothermal heating system. For this, Oylat Geothermal Central Heating System was selected. The investigation containing energy and exergy analysis was carried out between 1 January 2020 and 31 March 2020. The data were collected from the basis of the facility in questionby reviewing the computer displayswhich were systemized to control and observe the operating conditionals of the system and by holding a consultation with technical staff of that facility. In addition to this, the system was examined on-site to acquire correct information about the systemdesign. The values about the heat pumps were collected from the department of the sales company in Istanbul, Turkey and the 'Monthly Average Values' were determined. On the basis of theoretical analysis, thermodynamic values belong to the system were detected. These values were used to obtain the final energy, exergy and thermoeconomic results. According to these results:

The energy and exergy efficiencies of the whole system were found as $56.77 \%$ and $49.93 \%$ respectively. Because the heat losses of the heat exchangers were negligible, the energy 
efficiencies of those were $100 \%$ and their exergy efficiencies were $57.73 \%$.The heat transfer efficiencies of the Heat Pump 1 and Heat Pump 2 were 93.96\% and 95.12\% respectively. However, their exergy efficiencies were $17.28 \%$ and $14.94 \%$ respectively. The lower exergy efficiencies of the heat pumps stem from their low Carnot efficiencies and high electricity consumptions in the compressors. The condensing combi boiler group transferred heat at $74.76 \%$ efficiency while the exergy efficiencies of this group was $13.93 \%$ caused of that the electricity consumption of this equipment was too higher than the exergy rate transferred to water heated. The energy and exergy efficiencies of the accumulating tank group were $68.21 \%$ and $78,42 \%$ respectively. Because this unit acquired more heat power than they conducted into the water in the district heating cycle, the energy efficiency in this unit found relatively low. The average exergy costs of all system elements were determined. The exergy costs from higher to lower, of the condensing combi boiler group, heat pump 1, heat pump 2, wall heating panels, accumulating tank group and all of circulating pumps were respectively $128.821 € / \mathrm{h}$, $115.596 € / \mathrm{h}, 111.531 € / \mathrm{h}, 33.555 € / \mathrm{h}, 19.916 € / \mathrm{h}$ and $1.608 € / \mathrm{h}$. The thermoeconomic factor for the entire system was calculated as $9.8 \%$. Since this value was relatively low in the accumulating tank group, condensing combi boiler group and heat pump 2, in the possible optimisation study of these units, the exergy destructions should be taken into consideration.

\section{CONFLICT OF INTEREST}

The author(s) confirm that there is no known conflict of interest or common interest with any institution/organization or person.

\section{AUTHOR CONTRIBUTION}

Nurettin Yamankaradeniz: Determination of conceptual and/or design processes of the study, management of conceptual and/or design processes of the study, data analysis and interpretation, writing the draft of the manuscript, reviewing the intellectual content, final approval and full responsibility of the study. Orhan Şahmerdan: Determination of conceptual and/or design processes of the study, management of conceptual and/or design processes of the study, data collecting, data analysis and interpretation, reviewing the intellectual content.

\section{REFERENCES}

1. Acar, C., Dincer, I. (2017) Environmental impact assessment of renewables and conventional fuels for different end use purposes, International Journal of Global Warming, 13, 260-277. doi:10.1504/IJGW.2017.087197

2. Akbulut, U., Utlu, Z., Kincay, O. (2016) Exergy, exergoenvironmental and exergoeconomic evaluation of a heat pump-integrated wall heating system, Energy,107,502-522.doi: 10.1016/j.energy.2016.04.050

3. Aleixandre-Tudo, J.L., Castello-Cogollos, L., Aleixandre, J.L., Aleixandre-Benavent, R. (2019) Renewable energies: worldwide trends in research, funding and international collaboration, Renewable Energy, 139, 268-278.doi:10.1016/j.renene.2019.02.079

4. Bhowmika, C., Bhowmika, S., Rayb, A., Pandeya, K.M. (2017) Optimal green energy planning for sustainable development, Renewable and Sustainable Energy Reviews, 71, 796813. doi:10.1016/j.rser.2016.12.105

5. Blazquez, C.S., Martin, A.F., Nieto, I.M., Gonzalez-Aguilera, D. (2018) Economic and environmental analysis of different district heating systems aided by geothermal energy, Energies, 11, 1-17. doi:10.3390/en11051265 
6. Boles, M. and Cengel, Y. (1989) Thermodynamics: An Engineering Approach, Literatüre, Istanbul.

7. Boyaghchi, F.A., Chavoshi, M., Sabeti, V.(2015) Optimization of a novel combined cooling, heating and power cycledriven by geothermal and solar energies using the water/CuO (copperoxide) nanofluid,Energy, 91, 685-699.doi:10.1016/j.energy.2015.08.082

8. Byrne, P. and Ghoubali, R. (2019) Exergy analysis of heat pumps for simultaneous heating and cooling, Applied Thermal Engineering, 149, 414-424. doi:10.1016/j.applthermaleng.2018.12.069

9. Ebadollahi, M., Rostamzadeh, H., Pedram, M.Z., Ghaebi, H., Amidpour, M. (2019) Proposal and assessment of a new geothermal-based multigeneration system for cooling, heating, power, and hydrogen production, using LNG cold energy recovery, Renewable Energy, 135, 66-87. doi:10.1016/j.renene.2018.11.108

10. Ezzat, M.F. and Dincer, I. (2016) Energy and exergy analyses of new geothermal-solar based system, Solar Energy, 134,95-106. doi:10.1016/j.solener.2016.04.029

11. Ghaebi, H., Parikhani, T., Rostamzadeh, H. (2018) A novel trigeneration system using geothermal heat source and liquefied natural gas cold energy recovery: Energy, exergy and exergoeconomic analysis, Renewable Energy, 119, 513-527. doi:10.1016/j.renene.2017.11.082

12. Herez, A., Khaled, M., Murr, R., Haddad, A., Elhage, H., Ramadan, M. (2017) Using geothermal energy for cooling-parametric study , Science Direct, 119, 783-791. doi:10.1016/j.egypro.2017.07.111

13. Imal, M., Karapınar, C., Doğan O. (2013) The effect of natural gas use on air quality, a case study of K.Maras, KSU Journal of Engineering Sciences, 16, 22-28.

14. Kanoglu, M., Cengel, Y.A, Dincer, I. (2012)Efficiency Evaluation of Energy Systems, Springer, New York.doi:10.1007/978-1-4614-2242-6

15. Lazzaretto, A., Tsatsaronis, G. (2006) SPECO: a systematic and general methodology for calculating efficiencies and costs in thermal systems, Energy, 31, 12571289.doi:10.1016/j.energy.2005.03.011

16. Noorollahi, Y., Shabbir, M.S., Siddiqi, A.F., Ilyashenko, L.K., Ahmadi, E. (2019)

17. Review of two decade geothermal energy development in Iran, benefits, challenges and

18. future policy, Geothermics, 77, 257-266. doi:10.1016/j.geothermics.2018.10.004

19. Rostamzadeh, H., Gargari, S.G., Ghaebi, H. (2019) A novel multigeneration system driven by a hybrid biogas-geothermal heat source, Part II: Multi-criteria optimization, Energy Conversion and Management, 180, 859-888.doi:10.1016/j.enconman.2018.11.035

20. Singh, D.P., Dwevendi, A. (2019) Production of clean energy by green ways, Solution to Environmental Problems Involving Nanotechnology and Enzyme Technology, 49-90. doi:10.1016/B978-0-12-813123-7.00002-5

21. Soltani, M., Kashkooli, F.M., Dehghani-Sanij A.R., Kazemi, A.R., Bordbar N. Farshchi, M.J., Elmi, M., Gharali, K., Dusseault, M.B. (2019) A comprehensive study of geothermal heating and cooling systems, Sustainable Cities and Society, 44, 793818.doi:10.1016/j.scs.2018.09.036

22. Wang, X., Klemes, J.J., Dong, X., Fan, W., Xu, Z., Wang, Y., Varbanov, P.S. (2019) Air pollution terrain nexus: a review considering energy generation and consumption, Renewable and Sustainable Energy Reviews, 105, 71-85. 
Yamankaradeniz N., Sahmerdan O.: Energy Exergy Analysis. of a Geothermal Htg. Sys.

doi:10.1016/j.rser.2019.01.049 